\title{
Studying on the Polymer-Modified Concrete of Pavement Performance
}

\author{
Yiqin Shen ${ }^{1, a}$, Xiao Chen ${ }^{2, b}$, Hongjun Guo ${ }^{3, c}$, YuanhuiXiang ${ }^{1, d}$, Qinghai Liu ${ }^{4, e}$ \\ ${ }^{1}$ EXi Expressway Administration of Hubei Department of Transportation \\ ${ }^{2}$ Wuhan University of Technology \\ ${ }^{3}$ Hubei Safety \& Environment Technology Institute Co., Ltd. \\ ${ }^{4}$ Hubei Chang Jiang Rord\& Bridge

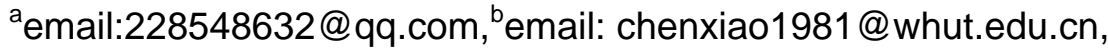 \\ cemail:412805409@qq.com, ${ }^{\mathrm{d} e m a i l: 171657742 @ q q . c o m, ~}{ }^{\mathrm{e} e m a i l: 18597096 @ q q . c o m}$
}

\begin{abstract}
Keywords: Polymer, Cement concrete, Pavement performance
Abstract. On account of cement concrete has many disadvantages,including pavement poor toughne ss, high brittleness, easy cracking and other fatal flaws, the concrete reinforced by polymer-modified fiber is recommended as a new building material. This paper focuses on studying the polymer-modi fied concrete of pavement performance. It contains flexural toughness, shrinkage resistance, wear- $r$ esisting property,anti-cracking ability.
\end{abstract}

\section{Introduction}

In many Chinese parts, cement concrete has been widely used as pavement material.It has many advantages ,such as a long service life, small maintained workload and less energy consumption.But cement concrete has many disadvantages, including pavement poor toughness, high brittleness, easy cracking and other fatal flaws[1].

Cresson has made natural rubber latex as filler putting in pavement construction materials since 1923. Polymer-modified concrete has over 90 years of history[2]. Thereafter fiber modified cement-based materials is gradually turned up, but most of the fiber is pulled from the concrete matrix after being destroyed, showing its effect has not been a real play.

Today, concrete rein forced by polymer-modified fiber rises in response to the proper time and conditions. According to relevant documentation. It has many research about mechanical properties [4], but its road performance about flexural toughness, shrinkage resistance, wear-resisting property, anti-cracking ability is not much, not enough depth, and relevant reports are also relatively small[5].

\section{Raw Materials and Test Method}

\section{Raw materials}

PO 42.5 cement using ordinary portland cement, meeting the relevant standards;PC-3301C water reducing agent; Shanghai styrene-butadiene latex (DB) produced by BASF.Aggregate particle size:1\#: $0-2.36 \mathrm{~mm}, 2 \#: \quad 2.36 \mathrm{~mm}-4.75 \mathrm{~mm}, 3 \#: 4.75-9.5 \mathrm{~mm}$.needle like: 8.2 percent.

\section{Test Method}

(1) Flexural toughness test

Using UTM25 tests the polymer modified mortar of flexural toughness,recording specimen load and deflection data. .

(2) Shrinkage resistance test

Shrinkage resistance test uses "falling weight method"recommended by American Concrete Institute (ACI) 544 Commission.

(3) Wear-resisting property test 
According to the special requirements about abrasion resistance on pavement material, molding $150 \mathrm{~mm} \times 150 \mathrm{~mm} \times 50 \mathrm{~mm}$ specimens, conducting wear-resisting property test according to "Highway Engineering Cement Concrete Test Rules" (JTJ053-94) .

\section{Experiments and Results}

\section{Research on road performance of polymer modified cement concrete materials}

As the paving material, polymer modified cement concrete must have excellent road performance. The material of the road performance is mainly manifested in resistance to bending toughness, impact, wear, early shrinkage crack and other aspects. Therefore, this section focuses on the systematic study of the above aspects of polymer modified cement concrete materials.In Experimental, Concrete proportion of mixture: cement $335 \mathrm{~kg} / \mathrm{m}^{3}$; aggregate gradation $1 \#(0-2.36 \mathrm{~mm}): 2 \#(2.36-4.75 \mathrm{~mm})$ : $3 \#(4.75-9.5 \mathrm{~mm})=4: 1: 5$; water-cement ratio 0.35 ; fiber content $0.14 \%$.

\section{Research on flexural toughness of polymer modified cement concrete materials}

The influence of the amount of emulsion on concrete flexural toughness is shown in Table 1. It can be seen that when mixed with polymer latex, the maximum deflection and the flexural toughness of the sample increases with the amount of the emulsion rises. The sample DB-100 can increase the maximum deflection at $74.7 \%$ and increase the flexural toughness at $108.4 \%$, as compared to the sample DB-0.

\begin{tabular}{cccc}
\hline \multicolumn{4}{c}{ Table 1 The influence of the amount of fiber and latex on } \\
concrete flexural toughness
\end{tabular}

\section{Research on the impact resistance of polymer modified cement concrete materials}

The influence of the amount of emulsion on concrete impact resistance is shown in Table 2. It can be found that when mixed with latex, the impact resistance increases with the increasing of the amount of the emulsion. And the impact performance of the sample DB-100 improved 4.2 times when compares to the sample DB-0. The failure patterns of the sample DB-0 and the sample DB- 90 after the completion of the impact test are shown in Fig.1. The failure pattern of the sample DB-90, compared with the sample DB-0, the number of cracks increase, the emergence and development of cracks are shown as radial, and cross section is not flat, which indicates that the polymer have crack resistance action on concrete.

Table2 Influence of polymer content on the impact resistance of PCC

\begin{tabular}{|c|c|c|c|c|}
\hline Number & $\begin{array}{l}\text { Impact times of } \\
\text { first crack/N1 }\end{array}$ & $\begin{array}{c}\text { Impact times of } \\
\text { destroy/Nc }\end{array}$ & $\Delta \mathrm{N}=\mathrm{N}_{1}-\mathrm{Nc}$ & $\begin{array}{c}\text { Impact energy } \\
\mathrm{W} / 10^{3} \mathrm{~N} \cdot \mathrm{m}\end{array}$ \\
\hline DB-0 & 291 & 293 & 2 & 5.91 \\
\hline DB-70 & 787 & 792 & 5 & 15.96 \\
\hline DB-80 & 1172 & 1180 & 8 & 23.78 \\
\hline DB-90 & 1399 & 1408 & 9 & 28.38 \\
\hline DB-100 & 1511 & 1524 & 13 & 30.75 \\
\hline
\end{tabular}



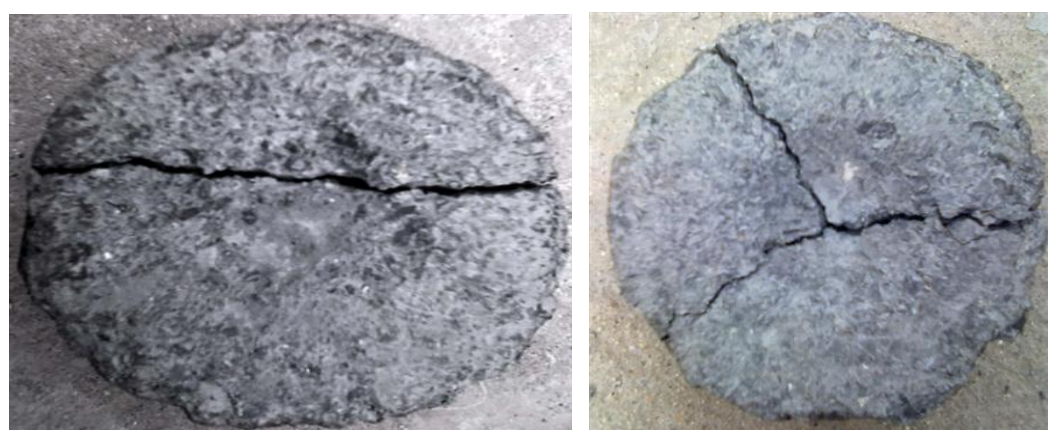

$\begin{array}{ll}\text { (a) Ordinary concrete 0-DB-00 } & \text { (b)Polymer concrete 90-DB-00 }\end{array}$

Fig.1 Sample morphology after the impact test

\section{Research on the wear resistance of polymer modified cement concrete materials}

The influence of the polymer on the wear resistance of the polymer modified cement concrete material is shown in Table 3. It shows that its wear resistance of the sample gradually improved with the increasing of the amount of polymer. The sample DB-100 can reduce the amount of wear at $13.1 \%$ when compared with the sample DB-70. Whereas compared to the sample DB- 0 , it can reduce the wear at $42.9 \%$.

\begin{tabular}{cccc}
\multicolumn{4}{l}{ Table 3 Effect of polymer on the wear resistance of PCC } \\
\hline Number & $\begin{array}{c}\text { Unit amount of } \\
\text { wear } /\left(\mathrm{kg} / \mathrm{m}^{2}\right)\end{array}$ & Number & $\begin{array}{c}\text { Unit amount of } \\
\text { wear } /\left(\mathrm{kg} / \mathrm{m}^{2}\right)\end{array}$ \\
DB-0 & 4.89 & 0 -DB-12 & 3.11 \\
DB-70 & 3.21 & 0 -DB-14 & 3.01 \\
DB-80 & 3.08 & $90-\mathrm{DB}-10$ & 2.77 \\
DB-90 & 2.92 & $90-\mathrm{DB}-12$ & 2.21 \\
DB-100 & 2.79 & $90-\mathrm{DB}-14$ & 2.23 \\
\hline
\end{tabular}

\section{Study on anti-cracking ability of polymer-modified cement concrete materials}

For anti-cracking ability of polymer emulsion modified cement-based materials, the test concrete pr oportion of mixture and the test results are shown in Table 4.

Overall opinion: The sample A-0 earliest cracks and crack the most serious; and compared with $t$ he sample A-0, It shows that with the adding of the amount of polymer, the cracking time can be $p$ rolonged, the cracks can be reducing, and it can better improve its anti-cracking ability. With the in creasing of the amount of polymer, cracking time gradually increased, when emulsion adds in an a mount of $164 \mathrm{~g}$, the cracking time can be prolonged at $101.9 \%$.

Table 4 the test of concrete proportion of mixture and results

\begin{tabular}{|c|c|c|c|c|c|c|c|c|}
\hline \multirow[b]{2}{*}{$\begin{array}{l}\text { serial } \\
\text { number }\end{array}$} & \multicolumn{6}{|c|}{ cement mortar ratio } & \multirow[b]{2}{*}{$\begin{array}{l}\text { initial cracking } \\
\text { time }\end{array}$} & \multirow[b]{2}{*}{$\begin{array}{l}\text { Fracture character } \\
\text { description }\end{array}$} \\
\hline & $\begin{array}{c}\text { cement } \\
/(\mathrm{g})\end{array}$ & $\begin{array}{l}\text { River } \\
\text { sand/ } \\
(\mathrm{g})\end{array}$ & $\begin{array}{c}\mathrm{DB} / \\
(\mathrm{g})\end{array}$ & $\begin{array}{l}\text { fiber volume } \\
\text { percent } /(\%)\end{array}$ & $\begin{array}{l}\text { water/ } \\
(\mathrm{g})\end{array}$ & $\begin{array}{l}\text { water } \\
\text { reducer } \\
\qquad /(\mathrm{g})\end{array}$ & & \\
\hline A-0 & 600 & 1200 & 0 & 0 & 240 & 3 & 58.4 & longest, widest \\
\hline A-1 & 600 & 1200 & 127 & 0 & 180 & 3 & 88.1 & Longer, wider \\
\hline A-2 & 600 & 1200 & 164 & 0 & 120 & 3 & 117.9 & narrow, short, \\
\hline
\end{tabular}




\section{Conclusions}

(1) When concrete is mixed with polymer latex, the maximum deflection and the flexural toughness of the sample increases with the amount of the emulsion rises. The sample DB-100 increase the flexural toughness at $108.4 \%$, as compared to the sample DB-0.

(2) When concrete is mixed with polymer latex, the impact resistance increases with the increasing of the amount of the emulsion.the impact performance of the sample DB-100 improved 4.2 times when compares to the sample DB-0.

(3)When concrete is mixed with polymer latex, the wear resistance of the sample gradually improved with the increasing of the amount of polymer. The sample DB-100 can reduce the amount of wear at $42.9 \%$ when compares to the sample DB-0.

(4)With the increasing of the amount of polymer, cracking time gradually increased, when emulsio $\mathrm{n}$ adds in an amount of $164 \mathrm{~g}$, the cracking time can be prolonged at $101.9 \%$.

In summary, through the research of DB latex effect on the cement concrete materials, it can been found that DB latex can better improve the pavement performance.

\section{Acknowledgements}

This work was financially supported by the National Natural Science Fund (51402226) and Hubei province transportation science and technology project (20130113).

\section{References}

[1] Davidovits J. Geopolymer chemistry and application [M]. Geopolymer Institute, SaintQuentin, France, 2008:3-15

[2] Wang Qing, Ding Zhao Yang, Zhang J,Qui L G,Sui Zhi Tong. Study on slag-based geopolymer hydration process[J]. Key Engineering Materials (2011)477:67-71

[3] J.C.Swanepoel, C.A.Strydom.Utilisation of fly ash in a geopolymeric material[J]. Applied Geochemistry, 2002, 17(8):1143-1148.

[4] Van Jarsveld J G S, Van Deventer J S J, Lukey G C. The effect of composition and temperature on the properties of fly ash and kaolinite-based geopolymers[J]. Chemical Engineering Journa,1 2002, 89:63 73.

[5] Beeldens A,Van Gemert D,Schorn H, et al. From microstructure to macrostructure: an integrated models of structure formation in polymer-modified concrete[J].Materials and structures ,(2005). 